\title{
Evaluating Enjoyment Within Alternate Reality Games
}

\author{
Andrew P. Macvean* \\ School of Mathematical and Computer Sciences \\ Heriot-Watt University
}

\author{
Mark O. Riedl ${ }^{\dagger}$ \\ School of Interactive Computing \\ Georgia Institute of Technology
}

\begin{abstract}
Alternate Reality Games (ARGs) are interactive narrative experiences which use the real world as the platform of the game. By bringing play out into the real world, ARGs provide players with an opportunity to enjoy both the gameplay, and benefit from the rich social experiences and physical activity which come synonymously with the genre. Due to its recent emergence, very little is known on what makes for an enjoyable ARG experience. What can we take from traditional game literature and where does this genre demand changes in our understanding? In this paper we present out work on understanding the player experience within ARGs. We look at the existing literature on enjoyment within video games, and use this to devise a set of new criteria. Through a preliminary validation of our metric, we found that a game which scores well using our analysis is significantly more likely to be enjoyed than a game which scores relatively low. In the process, we found that some of the key components of an enjoyable traditional video game experience are not so essential when considering ARGs.
\end{abstract}

CR Categories: K.8.0 [Computing Milieux]: Personal Computing-Games; H.5.1 [Information Interfaces and Presentation]: Multimedia Information Services-Artificial, augmented, and virtual realities H.5.2 [Information Interfaces and Presentation]: User Interfaces-Evaluation / Methodology, User-centred design

Keywords: Alternative Reality Games, Pervasive Gaming, Enjoyment, Flow, Evaluation, Game Play

\section{Introduction}

Whether developing a video game solely for entertainment, or with ulterior motives such as educating or facilitating behavioural change, making for an enjoyable experience remains one of the most important aspects for consideration. In the ever evolving area of video game development, a relatively new genre known as 'Pervasive Gaming' has recently emerged. Pervasive games aim to blur the lines between the virtual world of the game and the real world of the player in order to bring a more immersive and entertaining game experience. One technique regularly used to facilitate such gameplay is location tracking, using the physical location of the player and their subsequent movement as a means of interaction with the game.

\footnotetext{
*e-mail:apm8@hw.ac.uk

†e-mail:riedl@cc.gatech.edu
}

By bringing the player out into the real world, the player can also benefit from the type of rich social experiences and physical activity not possible playing a console game. Magerkurth et al. explain "Pervasive games are no longer confined to the virtual world domain of the computer but integrate the physical and social aspects of the real world" [Magerkurth et al. 2005]. Pervasive games have been studied and the Pervasive GameFlow Model (PGF) [Jegers 2007] was established to capture the criteria of enjoyment particular to pervasive games. The PGF extends Csikszentmihalyi's notion of optimal experience [Csiksentmihalyi 1990], and its application within traditional video gaming, to capture the unique affordances of pervasive gaming.

In our work, we are interested in one specific sub-genre of pervasive gaming known as Alternate Reality Games (ARGs). Layering a fictional world over the real world, ARGs provide an interactive narrative experience played out in the physical world of the player. Although a sub-genre of pervasive games, the emphasis on the narrative experience brings with it even more unique and novel considerations not normally associated with game development.

Through extra focus on the narrative aspects, and less emphasis on traditional pervasive gaming mechanics, including for example skill level and rewards, the question arrises: to what extent do the previously devised enjoyment metrics capture the key and influential considerations, important for this style of gaming? In this paper we discuss the novel demands of ARGs and how preexisting enjoyment metrics are not suitable for accurately assessing enjoyment within the genre. We contribute our own metric for evaluating enjoyment within ARGs, highlighting where this metric can be linked to PGF and where the PGF model cannot capture the novel demands of the genre.

Our paper is organized as follows. First, we provide greater detail on the sub-genre of Alternate Reality Games and provide a background on evaluating enjoyment in games. In Section 4 we present our metric. In Section 5 we describe our preliminary study in order to validate the metric. Finally, we draw a set of conclusions on our metric, and how our new understanding relates to traditional video game enjoyment.

\section{Alternate Reality Games}

Alternate Reality Games are interactive narrative experiences which work by layering a fictional world over the real world of the player. As the player navigates the real world, their movement influences the state of the fictional world. A key concept of ARGs is the believable nature of the alternative reality. One technique regularly used within the genre is the idea that the player is not in fact playing a game at all [Sotamaa 2002]. Rather than simply participating in a game, the player is made to feel that game events are actually real world events and thus the game should support such a way of thinking.

Sean Stewart describes an ARG as "a story which is broken into pieces which the audience must find and assemble" [Stewart 2010]. From this we can establish two key principles. ARGs by definition are predominantly story based games. While other pervasive games can rely on more traditional gameplay mechanisms, for example team competition / collaboration [Benford et al. 2005; Barkhuus 
et al. 2005] as the primary means to facilitate enjoyment, within ARGs the primary enjoyment mechanism comes from story based elements. Second of all, an ARG must have a modular story structure, with the game split into small independent pieces, and subsequently scattered throughout the real world. The story is then told in small sections as the player travels from location to location, each new place bringing a new and connected piece of the narrative.

According to Stewart [2010], "The audience is not only brought into the world because THEY are the ones responsible for exploring it, the audience also meaningfully affects how the story progresses. It is built in a way that allows players to have a key role in creating the fiction." Therefore, it is the player's responsibility to 'assemble the pieces', the game should allow for non linearity in the story structure and contain key user-decision points at which the player will make choices that affect their journey through the story. Where other games can follow a more linear structure and rely on other elements to harbor enjoyment, for example character personalisation, this is not the case within ARGs. From these definitions of what makes an ARG, it is clear that the emphasis is on the narrative of the game, adding unique demands and considerations not present within all pervasive games.

\section{Game Enjoyment}

Csikszentmihalyi's work on Flow [Csiksentmihalyi 1990] (the theory of an optimal experience) is widely regarded as the foundation of understanding enjoyment. Through his work, Csikszentmihalyi constructed a set of eight criteria which, if fulfilled during a task, should result in an optimal experience. As well as constructing these eight criteria, Csikszentmihalyi made two significant findings on enjoyment, namely, optimal experience is the same all over the world, and also enjoyment is the same irrespective of social class, age or gender.

Utilizing Csikszentmihalyi's theory on Flow, Sweetser and Wyeth developed an altered version of the model, designed specifically to capture the essence of Flow within video games [Sweetser and Wyeth 2005]. While this model is widely regarded as an effective evaluator of enjoyment within games, the progression of technology, and the subsequent novel demands brought about by pervasive games, meant that new considerations had to be made. An abbreviated version of the Pervasive GameFlow model [Jegers 2007] is presented in Table 3, criteria listed in italics are additions which Jegers made to the existing GameFlow model.

\section{ARG Enjoyment}

Due to the unique demands of ARGs, an emphasis on the narrative aspects rather than traditional video game mechanisms, we are forced to question the suitability of the Pervasive GameFlow model for accurately capturing the key elements of an enjoyable ARG experience. For example, the PGF model states "games should include online help so players don't need to exit the game". This hardly seems suitable when the aim of the game is to create a convincing alternate reality. That being said, many of the criteria which make up the eight elements of the PGF model are still highly applicable within ARGs. In this section, we outline 5 key principles which we believe to make for an enjoyable ARG experience. Each of the criteria is then linked back to the PGF model showing the principles we are basing our work on. The PGF model is shown, in abbreviated form, in Table 3 at the end of this paper.

Strong Narrative Structure - Requirement (I) This principle outlines the need for a strong basic story, a generalised principle based upon traditional narrative research. (a) No dead ends, the final outcome should always be complete and meaningful.

(b) The game should make use of traditional narrative elements, Propp [Propp 1968] and Aristotel [Halliwell 1987].

(c) The game should contain a number of problems which the player is required to solve [Rumelhart 1977].

(d) The narrative should support the creation of both the overall goal of the game as well as a number of sub-goals, the resolution of which will lead to the fulfilment of the overall goal.

(e) The narrative should support the player in their progress towards the goal, making it clear how they are progressing.

This requirement links back to the following elements in the PGF model; Challenge (bullet 4), Control (bullet 3), Clear Goals (bullet 1, 2), Feedback (bullet 1, 2, 3), Immersion (bullet 1, 2, 3, 4) and Social Interaction (bullet 5).

Modular Structure - Requirement (II) Working on the basis of a story which is spread throughout the world, all game content should be split into small modular pieces.

(a) The game should be presented in small modular pieces.

(b) It should be the players job to assemble these pieces in whatever manner they wish.

The modular structure requirement links back to the PGF notion of Challenge (bullet 3,4) and Control (bullet 5, 6).

Meaningful Story Pieces - Requirement (III) It is particularly important in a story based game that all content is meaningful and plays a role in the formation of the game. As the overall goal is that a realistic and convincing alternate reality is being created, all elements of the game should consistently and convincingly play a role in the overall illusion.

(a) Each piece should play a role in the overall outcome of the game.

(b) The pieces should appear in a logical order.

(c) players should feel all elements of the game fit within the alternate reality created by the game.

The requirement of meaningful story pieces is linked to the PGF notion of Concentration (bullet 2, 3) and Immersion (bullet 3, 4).

Interactivity - Requirement (IV) It is particularly important that the player is afforded the opportunity to interact with the system, and that the player feels such interactions were meaningful and influence the direction of the story.

(a) The decisions and actions of the player should influence the overall outcome of the game.

(b) The player should feel that the decisions had an affect on the game they experience.

(c) While the player should have control, there should be constraints such that the player does not stray too greatly or feel lost in what they are trying to achieve.

The requirement of interactivity links back to the PGF notions of Challenge (bullet 4) and Control (bullet 1, 4,6).

Skill Level - Requirement (V) In ARGs, the skill is set by the content of the game alone. It is particularly important that game content is generalizable to a wide audience. 
Table 1: ARG Enjoyment Metric.

\begin{tabular}{|l|l|}
\hline Criteria & Link \\
\hline $\begin{array}{l}\text { The game contained an appropriate intro- } \\
\text { duction }\end{array}$ & I (b)(d)(e) \\
\hline $\begin{array}{l}\text { The game contained appropriate sub goals at } \\
\text { each location }\end{array}$ & I (c)(d) \\
& II (a)(b) \\
II (b)(c) \\
V (a) \\
\hline $\begin{array}{l}\text { The game characters were interesting and } \\
\text { relevant }\end{array}$ & I (b) \\
& III (a)(c) \\
\hline V (a)
\end{tabular}

(a) The game should be suitable for play by a general audience. Therefore, clues should not be personal to the developer or contain references which make no sense to a wider audience.

(b) The game should show progression in difficulty, allowing for a basic introduction and culminating in a climatic conclusion.

The requirement of skill level links to the PGF notion of Player Skill (bullet 1, 2, 4, 5).

Based on our key principles we created a metric to assess player enjoyment within an ARG.

In Table 1 we present the metric as a set of 11 principles along with a link to the requirements which were taken into consideration.

\section{Validating the Metric}

We conducted a small scale investigation in order to validate our metric. Two games, one designed to score well on the metric, one to score relatively poor, were developed using WeQuest, an ARG authoring tool [Barve et al. 2010]. The purpose of the evaluation was to ensure that where we felt the game should score high / low, so too did members of the game playing community. Further to this, we wanted to gather early information on what game made for a more enjoyable experience. In order to control external influences

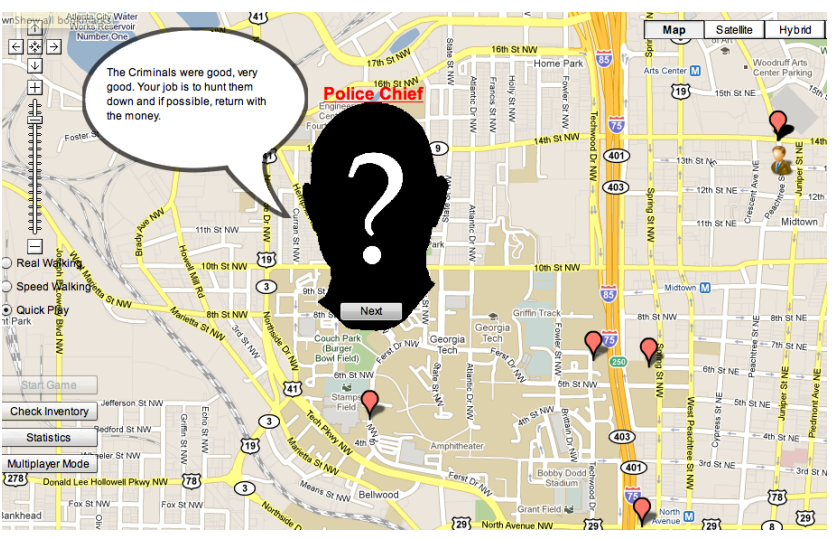

Figure 1: The game play interface showing a dialogue between the player and $a \mathrm{NPC}$.

which could affect enjoyment of a narrative, for example the theme of the story, both games were designed with the same overall plot $^{1}$, but with different narrative structures.

\subsection{Procedure}

Seven participants were recruited to mark both games for each of the 11 criteria in the metric. Each participant played each game twice, in order to explore different paths through the narrative. Participants played the game in a simulated environment, shown in Figure 1. The study was conducted in the simulated desktop environment due to the onerous nature of playing two games in the real world. The interface allows participants to move a small character around the map, simulating movement in the real world. After playing each game, the participants were provided with the 11 criteria, in Table 1, with natural language descriptions of what each criteria required. For each of the 11 criteria, participants rated each game on a 5-point scale. Additionally each player was asked to comment on which game they enjoyed playing more, in order for us to preliminarily assess the link between a games score in the metric, and how enjoyable it is to play.

\subsection{Results}

Table 2 shows the average score each of the two games received for all of the 11 criteria. When referring to the 'Good' game we mean the game designed to score well using the metric, while the 'Bad' game was the game intentionally designed to score poorly.

As one can see from Table 2, in all 11 categories, the 'Good' game scores higher than the 'Bad' game. The difference is statistically significant, at most $p<0.05$, in 7 of the 11 categories (marked with an*). The standard deviation for the 'Bad' Game is also consistently higher than that of the 'Good' game, showing that 'Bad' Game was more likely to split the opinion of the players, with far more variety present in the results obtained. Figure 2 shows the overall average score for each game, calculated using the individual scores for each of the 11 criteria. The 'Good' game scored significantly higher, $p<0.01(t=3.23)$, than the 'Bad' game.

In terms of enjoyment, all 7 participants enjoyed the 'Good' game more, conforming our hypothesis that a game which scores well using the criteria, is more likely to be enjoyed than a game which scores relatively poorer.

\footnotetext{
${ }^{1}$ The plot of a story refers to the high level outline of events.
} 


\section{Discussion}

From the results, we can see that the two games developed are statistically different in 7 of the 11 categories, with the 'Good' game scoring higher in all 11 categories. Interestingly, as our games differ significantly in only 7 of the 11 categories, we are left to question the importance of each of the 11 categories. We therefore want to investigate the role each of the criteria serves in influencing the overall enjoyment, and in doing so, establish weightings in order to accommodate importance within the model.

\begin{tabular}{|l|l|l|l|l|}
\hline Criteria & $\begin{array}{l}\text { Good } \\
\text { Game Avg }\end{array}$ & $\begin{array}{l}\text { Std } \\
\text { Dev }\end{array}$ & $\begin{array}{l}\text { Bad } \\
\text { Game Avg }\end{array}$ & $\begin{array}{l}\text { Std } \\
\text { Dev }\end{array}$ \\
\hline $\begin{array}{l}\text { Appropriate Introduc- } \\
\text { tion* }\end{array}$ & 4.5 & 0.5 & 2.5 & 0.8 \\
\hline Appropriate Sub-Goals & 4.2 & 0.5 & 3 & 0.8 \\
\hline $\begin{array}{l}\text { Interesting and Rele- } \\
\text { vant Characters* }\end{array}$ & 4 & 0.6 & 2.8 & 1.3 \\
\hline Relevant Locations & 3.3 & 0.8 & 2.8 & 1.3 \\
\hline Satisfying Ending* & 4 & 0.9 & 2.2 & 0.9 \\
\hline No Dead Ends* & 4.7 & 0.8 & 2.2 & 1.2 \\
\hline $\begin{array}{l}\text { Relevant Location Con- } \\
\text { tent }\end{array}$ & 4.2 & 0.8 & 3.2 & 1.3 \\
\hline Interesting Sub-Goals* & 4 & 0.9 & 2.7 & 1.0 \\
\hline Overall Player Control* & 4.3 & 0.8 & 2.6 & 1.2 \\
\hline Modular & 4.2 & 0.4 & 3 & 1.3 \\
\hline Difficulty* & 4.2 & 0.9 & 2.7 & 1.0 \\
\hline
\end{tabular}

In our games, where enjoyment was based primarily on principles from narrative literature, and the way in which we create enjoyable stories, we can conclude that some of the elements from the PGF model are no longer applicable. Where traditional game literature examines 'Player Skills', they are considering the skill set required to play the game. However, in ARGs where the goal is to create an alternate reality, in which the player is them self, it is important that the skills required for the game are those they already possess. We saw from our results difficulty does still play a role, but not in the same way we generally associate with video gaming. We also consider the importance of rewards within traditional video gaming. Research has shown game rewards, points, items, etc, play an important role within traditional video games [Hsu et al. 2005]. However, in the case of an ARG, the reward of the game is the unveiling of the story itself, much like what we see in the case of novels and movies. We see this in our results, through the statistically different evaluation of key narrative criteria, e.g. appropriate introduction, interesting and relevant characters, no dead ends and satisfying ending and the role this plays in the overall enjoyment of the player.

We also saw from our results four criteria which played no significant role in the overall enjoyment of our players. As discussed previously, ARGs are by nature modular games. It was therefore important that both games developed for this evaluation were modular and thus it is no surprise our participants identified this. In our evaluation we found both games scored similarly for relevance of locations and relevance of location content. This is because to ensure playability, location content had to make sense, otherwise players would find themselves lost and unable to play the game. Although in our example these criteria played no role in the overall enjoyment observed, we hypothesise that if we were to isolate one of these criteria, and create games significantly different in just that respect, we would see a significant difference in the enjoyment of our players.

With an insight into the metric, the next stage in the process is to gain a better understanding of the role each of the criteria plays on overall enjoyment. We also plan on running a large scale evaluation with participants playing the games out in the real world, in order to ensure the proposed metric remains valid.

The existence of four criteria found to be insignificant suggests that we must treat ARGs differently from other pervasive games. However, even at this preliminary stage, we believe that the seven statistically significant criteria, listed below, can be used to accurately evaluate enjoyment within an ARG: Appropriate Introduction; Interesting and Relevant Characters; Satisfying Ending; No Dead Ends; Interesting Sub Goals; Overall Player Control; Difficulty. Therefore, we see this as a first step towards an understanding of this emergent genre of pervasive video gaming.

\section{Acknowledgements}

We would like to thank SICSA for their continued funding and support. 

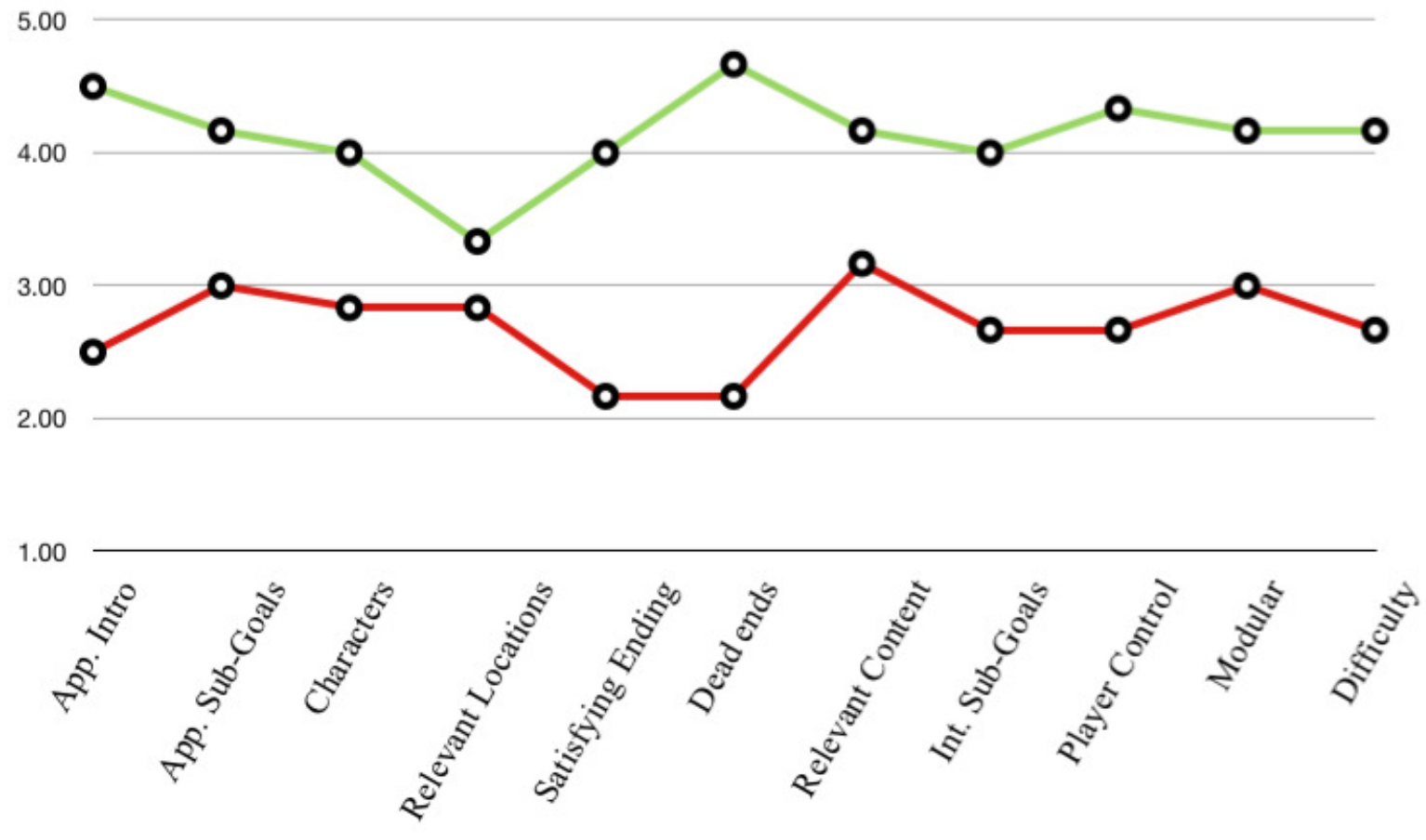

Figure 3: Comparison of the average individual category scores for both games.

\section{References}

Barkhuus, L., Chalmers, M., Tennent, P., Hall, M., Bell, M., Sherwood, S., AND Brown, B. 2005. Picking pockets on the lawn: The development of tactics and strategies in a mobile game. In Proceedings of the 7th International Conference on Ubiquitous Computing, Springer, Lecture Notes in Computer Science, 358-374.

Barve, C., Hajarnis, S., Karnik, D., And Riedl, M. O. 2010. Wequest: A mobile alternative reality gaming platform and intelligent end-user authoring tool. In Proceedings of the 6th Conference on Artificial Intelligence for Interactive Digital Entertaiment.

Benford, S., Rowland, D., Flintham, M., Drozd, A., Hull, R., Reid, J., Morrison, J., And FACER, K. 2005. Life on the edge: Supporting collaboration in location-based experiences. In Proceedings of the SIGCHI Conference on Human Factors in Computing Systems, ACM Press, $721-730$.

Bleumers, L., JacobS, A., AND VAN Lier, T. 2010. Criminal cities and enchanted forests: a user-centred assessment of the applicability of the pervasive gameflow model. In Proceedings of the 3rd International Conference on Fun and Games, ACM Press, 38-47.

Csiksentminalyi, M. 1990. The Psychology of Optimal Experience. Harper Perennial.

Halliwell, S. 1987. The Poetics of Aristotle, translation and Commentary. Duckworth.
Hsu, S. H., LEE, F. L., AND Wu, M. C. 2005. Designing action games for appealing to buyers. Cyber Psychology and Behavior. 8, 6 (December), 585-591.

JEGERS, K. 2007. Pervasive game flow: understanding player enjoyment in pervasive gaming. ACM Computers in Entertainment 5,1 (January).

Magerkurth, C., Cheok, A. D., MandryK, R. L., AND NilsEN, T. 2005. Pervasive games: bringing computer entertainment back to the real world. ACM Computers in Entertainment 3, 3 (July).

Propp, V. 1968. The Morphology of the Folktale. University of Texas Press.

RUMELHART, D. E. 1977. Understanding and summarizing brief stories. LaBerge, D., and Samuels, S. J. (eds). Basic Processes in Reading: Perception and Understanding, 265-303.

SotamaA, O. 2002. All the world's a botfighter stage: Notes on location-based multi-user gaming. In Proceedings of Computer Games and Digital Content Conference, Tempere University Press, 35-45.

STEWART, S., 2010. Alternate reality games. http://www.seanstewart.org/interactive/args/.

SWeEtSER, P., AND Wyeth, P. 2005. Gameflow: a model for evaluating player enjoyment in games. ACM Computers in Entertainment 3, 3 (July). 
Table 3: Pervasive GameFlow Model.

\begin{tabular}{|c|c|c|c|}
\hline Element & Criteria & Element & Criteria \\
\hline $\begin{array}{lr}\text { Player } & \text { Skills } \\
\text { Games } & \text { must } \\
\text { support } & \text { player } \\
\text { skill } & \text { devel- } \\
\text { opment } & \text { and } \\
\text { mastery } & \end{array}$ & $\begin{array}{l}\text { 1. players should be able to start playing the } \\
\text { game without reading the manual } \\
\text { 2. learning the game should not be boring, but be } \\
\text { part of the fun } \\
\text { 3. games should include online help so players } \\
\text { don't need to exit the game } \\
\text { 4. players should be taught to play the game } \\
\text { through tutorials or initial levels that feel like } \\
\text { playing the game } \\
\text { 5. players should be rewarded appropriately for } \\
\text { their effort and skill development } \\
\text { 6. game interfaces and mechanics should be easy } \\
\text { to learn and use } \\
\text { 7. Pervasive games should be very flexible and } \\
\text { enable the players' skills to be developed in a } \\
\text { pace set by the players }\end{array}$ & $\begin{array}{l}\text { Control Play- } \\
\text { ers should feel } \\
\text { a sense of con- } \\
\text { trol over their } \\
\text { actions in the } \\
\text { game }\end{array}$ & $\begin{array}{l}\text { 1. players should feel a sense of control over } \\
\text { their characters or units and their movements } \\
\text { and interactions in the game world } \\
\text { 2. players should feel a sense of control over the } \\
\text { game interface and input devices } \\
\text { 3. players should feel a sense of control over the } \\
\text { game shell (starting, stopping, saving, etc.) } \\
\text { 4. players should not be able to make errors that } \\
\text { are detrimental to the game and should be sup- } \\
\text { ported in recovering from errors } \\
\text { 5. players should feel a sense of control and im- } \\
\text { pact onto the game world (like their actions } \\
\text { matter and they are shaping the game world) } \\
\text { 6. players should feel a sense of control over the } \\
\text { actions that they take and the strategies that } \\
\text { they use and that they are free to play the game } \\
\text { the way that they want (not simply discovering } \\
\text { actions and strategies planned by the game de- } \\
\text { velopers) } \\
\text { 7. Pervasive games should enable the players to } \\
\text { easily pick up game play in a constantly on- } \\
\text { going game and quickly get a picture of the } \\
\text { current status in the game world (in order to } \\
\text { assess how the state of the game has evolved } \\
\text { since the player last visited the game world) }\end{array}$ \\
\hline $\begin{array}{l}\text { Clear Goals } \\
\text { Games should } \\
\text { provide the } \\
\text { player with } \\
\text { clear goals at } \\
\text { appropriate } \\
\text { times }\end{array}$ & $\begin{array}{l}\text { 1. overriding goals should be clear and presented } \\
\text { early } \\
\text { 2. Pervasive games should support the players in } \\
\text { forming and communicating their own inter- } \\
\text { mediate goals }\end{array}$ & $\begin{array}{l}\text { Feedback } \\
\text { Players must } \\
\text { receive appro- } \\
\text { priate feedback } \\
\text { at appropriate } \\
\text { times }\end{array}$ & $\begin{array}{l}\text { 1. players should receive feedback on progress } \\
\text { toward their goals } \\
\text { 2. players should receive immediate feedback on } \\
\text { their actions } \\
\text { 3. players should always know their status or } \\
\text { score }\end{array}$ \\
\hline $\begin{array}{lc}\text { Social } & \text { Inter- } \\
\text { action } & \text { Games } \\
\text { should } & \text { support } \\
\text { and create } \\
\text { opportunities } \\
\text { for social } \\
\text { interaction }\end{array}$ & $\begin{array}{l}\text { 1. games should support competition and coop- } \\
\text { eration between players } \\
\text { 2. games should support social interaction be- } \\
\text { tween players (chat, etc.) } \\
\text { 3. games should support social communities in- } \\
\text { side and outside the game } \\
\text { 4. Pervasive games should support and enable } \\
\text { possibilities for game oriented, meaningful } \\
\text { and purposeful social interaction within the } \\
\text { gaming system } \\
\text { 5. Pervasive games should incorporate triggers } \\
\text { and structures (e.g. quests and events, fac- } \\
\text { tions, guilds or gangs) that motivate the play- } \\
\text { ers to communicate and interact socially }\end{array}$ & $\begin{array}{l}\text { Immersion } \\
\text { Players should } \\
\text { experience } \\
\text { deep but } \\
\text { effortless in- } \\
\text { volvement in } \\
\text { the game }\end{array}$ & $\begin{array}{l}\text { 1. players should become less self-aware and } \\
\text { less worried about everyday life or self } \\
\text { 2. players should experience an altered sense of } \\
\text { time } \\
\text { 3. players should feel emotionally involved in } \\
\text { the game } \\
\text { 4. players should feel viscerally involved in the } \\
\text { game } \\
\text { 5. Pervasive games should support a seamless } \\
\text { transition between different everyday contexts, } \\
\text { and not imply or require player actions that } \\
\text { might result in a violation of social norms in } \\
\text { everyday contexts } \\
\text { 6. Pervasive games should enable the player to } \\
\text { shift focus between the virtual and physical } \\
\text { parts of the game world without losing too } \\
\text { much of the feeling of immersion }\end{array}$ \\
\hline $\begin{array}{l}\text { Concentration } \\
\text { Games should } \\
\text { require concen- } \\
\text { tration and the } \\
\text { player should } \\
\text { be able to } \\
\text { concentrate on } \\
\text { the game }\end{array}$ & $\begin{array}{l}\text { 1. games should provide a lot of stimuli from dif- } \\
\text { ferent sources } \\
\text { 2. games must provide stimuli that are worth at- } \\
\text { tending to } \\
\text { 3. players shouldn't be burdened with tasks that } \\
\text { don't feel important } \\
\text { 4. games should have a high workload while still } \\
\text { being appropriate for the players' perceptual, } \\
\text { cognitive and memory limits } \\
\text { 5. Pervasive games should support the player } \\
\text { in the process of switching concentration be- } \\
\text { tween in-game tasks and surrounding factors } \\
\text { of importance }\end{array}$ & $\begin{array}{l}\text { Challenge } \\
\text { Games should } \\
\text { be sufficiently } \\
\text { challenging } \\
\text { and match the } \\
\text { player's skill } \\
\text { level }\end{array}$ & $\begin{array}{l}\text { 1. challenges in games must match the players' } \\
\text { skill levels } \\
\text { 2. games should provide different levels of chal- } \\
\text { lenge for different players } \\
\text { 3. Pervasive games should stimulate and support } \\
\text { the players in their own creation of game sce- } \\
\text { narios and pacing } \\
\text { 4. Pervasive games should help the players in } \\
\text { keeping a balance in the creation of paths and } \\
\text { developments in the game world, but not put } \\
\text { too much control or constraints on the pacing } \\
\text { and challenge evolving }\end{array}$ \\
\hline
\end{tabular}

